\title{
CHALLENGES EXPERIENCED WITH ONLINE TUTORING IN AN ODL INSTITUTION
}

Yvonne T. Joubert

orcid.org/0000-0003-4709-6188

University of South Africa

joubeyt@unisa.ac.za

\author{
Annette M. Snyman \\ orcid.org/0000-0001-5302-8769 \\ University of South Africa \\ snymaam@unisa.ac.za
}

\section{ABSTRACT}

The objectives of this exploratory qualitative study were to determine the challenges of online teaching that were experienced by e-tutors in an open distance learning (ODL) institution, and to suggest possible solutions to overcome these challenges. The study was conducted with a sample of 31 (out of a total of 50) e-tutors in the Human Resource Management Department. Two main open-ended questions were sent to e-tutors in this department via email, to be completed on a voluntary basis. The results indicated that the e-tutors experience challenges such as low participation and lack of commitment by students. Students prefer to interact with the lecturers directly, there is limited or no interaction between lecturers and e-tutors, the e-tutors experience a sense of isolation and feel that their training is inadequate, and students are unclear about the role of the e-tutor, have limited access to technology and experience administrative problems. By analysing the findings of the literature review, as well as the results of the exploratory qualitative study, the researchers were able to identify the solutions by means of which an ODL institution can overcome the challenges of e-tutoring and ensure greater success for both students and the institution.

Keywords: open distance learning; distance education; e-learning; e-tutoring; challenges; solutions

\section{INTRODUCTION}

Online teaching, and particularly e-tutoring, presents numerous challenges for both the e-tutor and the student. In this article, the researchers examine the challenges experienced by the e-tutors in a specific department of an open distance higher education institution. The open distance learning (ODL) institution where this study was conducted has large numbers of students from diverse backgrounds and they are widely spread over South Africa and internationally (Matoane and Mashile 2013); this

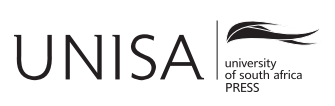


necessitated the implementation of the e-tutor model in 2013. Because this is a relatively new intervention, there is a need to explore the challenges and obstacles that have been experienced by the e-tutors thus far. Research on e-tutoring and online teaching, especially in an ODL institution is lacking. Research on the challenges of e-tutoring and online teaching in an ODL institution is entirely wanting. Through investigation of these challenges, the researchers were able to develop a plan to improve the e-tutor model in the future by overcoming the challenges and, in so doing, ensuring student success. Previous research studies have been done on the perceptions of both students and lecturers regarding e-learning, but not on the perceptions of e-tutors. This study specifically examined the perceptions of e-tutors regarding the challenges that they have experienced while serving as e-tutors.

\section{LITERATURE REVIEW}

The development of new technologies in higher education has advanced dramatically over the past few years (Abdullah and Mtsweni 2014). Higher education institutions are increasingly gearing themselves for the integration of information technology and online teaching mechanisms in their instructional practices (Mashile and Pretorius 2003). These technological advancements and increased reliance on technology make it imperative that ODL institutions use technology-enhanced learning as a means of academic support to students (Abdullah and Mtsweni 2014). ODL can be defined as a multidimensional concept aimed at bridging the time, geographical, economic, social, educational and communication-related distance between student and institution, student and academics, student and courseware, and student and peers (Holmberg 1995).

The aforementioned definition leads to the conclusion that ODL is focused on removing barriers to learning and providing more flexible and attainable access to learning for all students. ODL aims to provide student-centred learning and support and to construct learning programmes with the prospect of helping students to be more successful and satisfied (Abdullah and Mtsweni 2014). The most important aspect of ODL is that all systems in an institution (for example strategy, operations and academic and administrative activities, processes and infrastructure) have to be fully integrated to support the academic initiative and the student (Kilfoil n.d.). Open learning is an approach that embraces student-centredness in the following ways: through lifelong learning, flexibility of learning provision, removal of barriers to access to learning, recognition of prior learning, provision of student support, and construction of learning programmes with the expectation that students can succeed (Kilfoil n.d.). The only way in which an ODL institution can reach these various objectives successfully is through e-learning or online learning.

Distance education throughout the world is increasingly using e-learning and, given the changing face of educational provision and technological advancements around the world, the ODL institution where the study was conducted began to move towards e-learning through a model of e-tutoring in 2012 (Sieman and Allen in Muirhead 2007). 
E-learning can be defined as teaching that is delivered by means of computers using numerous forms, such as CD-ROMs and the Internet or intranet, which enable information to be delivered in various formats, such as graphics, videos, audios, animations, models, simulations and visualisations (Clark and Mayer 2003; De Rouin, Fritzsche, and Salas 2004). The purpose of e-learning also ensures that the content is relevant to the learning objectives of the particular module or subject, makes use of teaching methods such as practical examples and application to practice in order to facilitate learning, makes use of media elements such as words and images to enhance learning of the content, and builds new knowledge and skills linked to individual learning goals or to improved organisational performance (Clark and Mayer 2003).

E-tutoring is a form of e-learning that involves tutoring (teaching) in an online context, where the e-tutor offers personal guidance in a situation where regular face-toface contact between supervisor and student is difficult, such as in an ODL institution (Deketelaere et al. 2009). E-tutoring can play an important role in distance education and the use of communication technology can be used to market educational products, support communication and increase student support (Heydenrych, Higgs, and Van Niekerk 2003). E-tutoring has the main purpose of bridging the geographic gap and distance between students and their peers, and students and their lecturers (Matoane and Mashile 2013).

The ODL institution where this study was conducted accommodates large student numbers and has extremely high student enrolments when compared with residential universities (Matoane and Mashile 2013). The student profile of this ODL institution has also shifted over the past two decades: traditionally, its students were working adults, whereas now they are predominantly young people straight from school (Kilfoil n.d.). During the first semester of 2012, student enrolments totalled 360 000, which demanded a change on the part of the institution to become more student-centred and to offer greater student support (Matoane and Mashile 2013). The formal e-tutoring model was implemented for the first time in 2013, when e-tutors were appointed for all students in NQF Level 5 modules (E-connect 2015). In 2014, the e-tutor model was expanded to all NQF Level 6 modules, and in 2015, all NQF Level 7 modules were added to the model (E-connect 2015).

The effective interaction of the distance education student with the institution by means of e-tutoring creates a sense of satisfaction, belonging and fulfilment with the learning environment (Quon 2006). The key role of an e-tutor is to manage the online learning space effectively to ensure that it provides a suitable environment for effective learning to take place (Mashile and Matoane 2012). Gregory and Salmon (2013) describe the role of the e-tutor in an ODL context as promoting human interaction and communication through modelling, conveying and building of knowledge and skills in an online environment. The e-tutor performs the role of facilitator of learning, guiding students through the module content so that they are able to complete it successfully (Matoane and Mashile 2013). 
Furthermore, there are three important aspects that are crucial for e-tutoring at an ODL institution to be successful, namely participation of both the e-tutor and the students, contextualisation of the learning material to ensure that it is put into a meaningful and practical context, rather than being treated in isolation, and the presentation of the study material in the online context (Gregory and Salmon 2013). This is where most of the challenges arise, as will be discussed in the following section.

An e-tutoring model was implemented to bridge the learning gap in distance education in an ODL environment. It is therefore aimed at student support and student success (Matoane and Mashile 2013). However, there is a need to identify the challenges that were experienced by the e-tutors while tutoring online. Furthermore, it was needed to establish what can be done to overcome these challenges to ensure greater student and institutional success.

\section{PURPOSE OF THE STUDY}

The purpose of this study was to examine the challenges experienced by the e-tutors in an academic department of an open distance higher education institution. In an ODL institution, there is a great need for more collaboration between students and their peers, as well as between students and their lecturers or tutors. Through an online platform such as e-tutoring, students can be reached more easily throughout South Africa and internationally, than in the case of a paper-based system. The e-tutor model, which was implemented at the ODL institution where the study was conducted, aims to improve students' learning experience and their success rates (Matoane and Mashile 2013). The research objectives of this study were to determine the challenges experienced by e-tutors while e-tutoring, and to identify the possible solutions to overcome these challenges with the aim of contributing to greater student and institutional success.

\section{RESEARCH DESIGN AND METHODOLOGY}

\section{Research Approach}

This study took an exploratory qualitative research approach. Qualitative research examines the why and how of decision-making, not just what, where, when, or who, and has a strong basis in the field of sociology to understand government and social programmes (Leedy and Ormrod 2010). It is used to gain an understanding of underlying reasons, opinions, and motivations (Mouton 2001). Exploratory research intends merely to explore the research questions and does not intend to offer final and conclusive solutions to existing problems (Mouton 2001; Saunders, Lewis, and Thornhill 2009). Through the exploratory qualitative research approach, the researchers could give meaning to and interpret the e-tutors' experiences with regard to the methods they applied to encourage and increase students' participation online (Rice and Ezzy 
2002). Hence, the researchers decided to use a qualitative approach in order to generate new insights and ideas.

In this study, an interpretive paradigm was used because the researchers had to interpret and understand the challenges experienced by the e-tutors while teaching online (Saunders, Lewis, and Thornhill 2009). According to the Qualitative Research Guidelines Project (2008), the interpretive paradigm comprises the following beliefs about the nature of knowing and reality, namely 1) relativist ontology, which assumes that reality as we know it is constructed intersubjectively through the meanings and understandings developed socially and experientially, 2) transactional or subjectivist epistemology, which assumes that we cannot separate ourselves from what we know, and 3) the investigator and the object of investigation are linked such that who we are and how we understand the world is a central part of how we understand ourselves, others and the world.

\section{Research Procedure}

Participants who act as e-tutors for the Human Resource Management (HRM) Department at the ODL institution where the study was conducted were approached to participate in this study. Trustworthiness was improved by the researchers having been the e-tutor representatives of the Student Support Committee in the HRM Department for the past three years. The researchers also have personal experience with regard to the possible challenges the e-tutors might face with this new initiative (Krefting 1991). Lastly, the researchers are known to some of the e-tutors in this study, which was important for establishing good working relationships between the researchers and the e-tutors.

\section{Sample and Biographical Characteristics of the Participants}

The sampling method which was used in this study was purposive sampling. Purposive sampling, also referred to as judgement, selective or subjective sampling is a non-probability sampling method that is characterised by a deliberate effort to gain representative samples by including groups or typical areas in a sample (Saunders, Lewis, and Thornhill 2009). Through purposive sampling, 50 e-tutors in the HRM Department were identified. The criterion for inclusion in the sample was being an e-tutor in the HRM Department at the ODL institution where this study was conducted. The participants were encouraged to answer qualitative, open-ended questions on a voluntary basis; these questions were sent to the e-tutors via email. The reason the open-ended questions were emailed to the selected participants, instead of conducting interviews or focus groups is because the participants (e-tutors) are dispersed throughout South Africa, and through email, detailed feedback could be obtained from the participants without any cost due to transport or time taken from work obligations. A total of 31 out of the 50 e-tutors in the HRM Department took part in this study, which resulted in a 62 per cent uptake. The biographical characteristics of the participants are outlined in Table 1. 
Table 1: Biographical characteristics of the participants $(N=31)$

\begin{tabular}{|c|c|c|}
\hline Gender & Number & $\%$ \\
\hline Female & 20 & 65 \\
\hline Male & 11 & 35 \\
\hline Race & Number & $\%$ \\
\hline Black & 15 & 48 \\
\hline Coloured & 2 & 6.4 \\
\hline Indian & 3 & 9.6 \\
\hline White & 11 & 35 \\
\hline Age & Number & $\%$ \\
\hline $20-25$ & 0 & 0 \\
\hline $26-30$ & 4 & 13 \\
\hline $31-40$ & 6 & 19 \\
\hline $41-45$ & 7 & 23 \\
\hline $46-50$ & 6 & 19 \\
\hline $51-55$ & 2 & 6.4 \\
\hline $56-60$ & 4 & 13 \\
\hline $61-65$ & 2 & 6.4 \\
\hline Tenure (months) & Number & $\%$ \\
\hline $0-6$ & 4 & 13 \\
\hline $7-12$ & 6 & 19 \\
\hline $13-18$ & 7 & 23 \\
\hline $19-24$ & 5 & 16 \\
\hline $25-30$ & 5 & 16 \\
\hline $31-36$ & 4 & 13 \\
\hline Qualification & Number & $\%$ \\
\hline Grade 12 & 0 & 0 \\
\hline Diploma/certificate & 0 & 0 \\
\hline Degree & 6 & 19 \\
\hline Honours degree & 12 & 39 \\
\hline Master's degree & 12 & 39 \\
\hline Doctorate & 1 & 3 \\
\hline
\end{tabular}

From analysis of Table 1 it is evident that the majority of the participants were female $(65 \%)$ followed by male (35\%). Most of the participants were of African race $(48 \%)$ followed by white people (35\%). The age groups of the participants are dispersed over all the age categories, and the largest percentage fall within the category of 14-45 
(23\%) followed by 31-40 and 46-50 (both 19\%). The participants' tenure as e-tutors are mostly between $13-18$ months (23\%) followed by 7-12 months, $19-24$ months and 25-30 months (16\%). The majority of the participants have either a Master's degree $(39 \%)$ or an Honours degree (39\%) and a number of participants also have a Bachelor's degree $(19 \%)$, which sheds light on the fact that the participants are highly skilled and qualified individuals.

\section{Data Collection Methods}

The e-tutors from the HRM Department received open-ended questions via email. After the researchers received the e-tutors' responses, the researchers asked the e-tutors probing questions - by means of follow-up telephonic interviews - to clarify their initial written responses. This was done to ensure correspondence between the written and verbal responses. Data saturation occurred after interviewing 31 participants and there was no need to gather more information from the e-tutors.

\section{Data Analysis}

Recurring themes were identified from the e-tutors' responses. The researchers applied Tesch's (1990) content data analysis process. Tesch (1990) used eight steps in his data analysis process: (1) the verbatim evidence were typed and notes were made as they came to mind, (2) the most interesting interview was selected and main codes were identified, (3) a list of all the different topics were compiled, (4) the different topics were abbreviated as codes, (5) themes were created from wording that occurred the most from a specific topic, (6) the codes were alphabetised, (7) each theme's data were gathered and grouped with the theme, and (8) the findings were reported.

The themes identified in this study were:

a. Theme 1: Challenges experienced with online tutoring in an ODL institution.

b. Theme 2: Solutions to overcome the challenges identified in theme 1 .

\section{ETHICAL CONSIDERATIONS}

Ethical procedures were ensured in this study by informing the participants about the research; in addition, the researchers received an informed consent from each participant (Silverman 2002). The researchers maintained confidentiality by ensuring that the data were available only to the researchers. All the e-tutors remained anonymous and the data were not made available to them.

\section{FINDINGS OF THE STUDY}




\section{Theme 1: Challenges Experienced by the E-Tutors}

All the participants concurred that they experience certain challenges in their role as e-tutors. The researchers asked the following question: "Based on your views, what are the challenges you experienced as an e-tutor?” More than half of the participants $(54.8 \%, 17$ participants) were of the view that student participation is the main challenge they experience. A total of 16.13 per cent of the participants were also of the view that students are not committed and $9.7 \%$ indicated that the students prefer to communicate directly with the lecturer and not with the e-tutor. This is a matter of great concern, since if the students are not engaged, the aim of this module - namely to become more student-centred and to focus on effective interaction as a way of motivating students and promoting student success (Mashile and Matoane 2012) - cannot be achieved.

This concurs with the findings of studies conducted by $\mathrm{Du}$, Ochola, and Wernher (2013) and also Schonfeld (2005) which found that the foremost challenge of online learning is the lack of participation by students. Students' skills play an important part in successful online learning, and students do not always have the necessary skills and technological practicality to operate in an online learning environment (Mashile and Matoane 2012; Schonfeld 2005). Students' participation online is further affected by the quality of interaction between tutor and student which is lacking in most cases, as students spend more time typing responses than they do listening and learning (Matoane and Mashile 2013; Schonfeld 2005). Stern (2015) confirms this in a more recent study by concluding that one of the major challenges facing an online instructor is the replication of the interaction in a physical classroom and motivating students to interact with the teacher or tutor and with one another. Du, Ochola, and Wernher (2013) along with Todhunter (2013) noted similar problems with regard to e-tutoring, namely student barriers due to technological and technical variation in skills, lack of social interaction, lack of access to the Internet, technical problems and lack of collaboration between students.

This is especially true in the case of this specific study and the ODL institution where the research was conducted, because many of the interactions between e-tutors and students take place on the discussion forums, where responses are typed back and forth. Interaction creates relationships, and this is sometimes lacking in an online learning environment, especially because students have been found to be apathetic and fail to interact regularly and constructively with their teacher or tutor and their peers (Schonfeld 2005).

Some of the participants' responses with regard to students' lack of interaction were as follows:

Of the potential 200 learners, only 15 per cent interact with the e-tutor, it is either that the learning objectives are unclear or learners do not have the time to interact with the e-tutor. 
As an e-tutor I have experienced that some students do not respond to online messages posted by e-tutors, thus leading them not to have an understanding on how to do a particular assignment.

The responses of participants with regard to students' lack of commitment were as follows:

Students procrastinating and leaving their queries for the day before an assignment is due.

Students don't read their tutorial letters in time or as soon as they receive their material because they just read in passing and fail to understand the question.

In addition to the above responses, four of the participants $(12.9 \%)$ were concerned about the interaction between lecturers and e-tutors, as well as their sense of isolation $(19.35 \%)$. The e-tutor initiative cannot be a success if the e-tutor and lecturer are not lecturing the same content; moreover, the e-tutors cannot assist in student support if they do not get support from the lecturers. Distance education and ODL are characterised by geographical, physical, and, sometimes, historical separation of student and teacher or tutor, which leaves students to feel isolated (Townsend and Wheeler 2004). Du, Ochola, and Wernher (2013) and Mashile and Matoane (2012) are also of the view that students as well as e-tutors in an ODL environment often feel disconnected, isolated and demotivated. That is precisely why the ODL institution in this study developed the e-tutor programme; the aim is for students to learn from the e-tutors and one another, thus improving their learning experience and their success rate. But if the e-tutors are feeling isolated and experience a need to have more interaction with the lecturers, the purpose of the e-tutor initiative cannot be achieved. Some of the responses with regard to interaction between lecturer and e-tutors were as follows:

One of the challenges I experience is to make sure answers to questions of students are aligned with what the lecturer would have answered to the same question.

I experience the challenge to establish proper contact with the students. I get the impression that the lecturers don't want to interact with the e-tutors. I don't get any support from my e-tutor coordinator. He does not respond to my emails or telephonic messages. ... and there is no alignment between the different e-tutors involved in one module, in terms of their interaction with the student.

I struggle with assisting students with questions from previous question papers because there is no guidance from the lecturer.

Participants’ responses with regard to isolation were as follows:

The e-tutors are functioning individually and on their own and there is no alignment in terms of their interactions with the student.

The pilot site where the lecturers and the e-tutors can interact with each other is not active. This is concerning and extremely isolating. 
Three of the participants $(9.7 \%)$ were of the view that students prefer to interact with the lecturers and not the e-tutors. Earlier in this article we mentioned that the e-tutor initiative was developed so that e-tutors can provide interpersonal guidance to students because face-to-face contact between lecturers and students is problematic (Deketelaere et al. 2009; Du, Ochola, and Wernher 2013). Some of the participants' responses were as follows:

Students interact on the lecturers' site and although they enjoy the e-tutor's constant questions and reminders, they don't see why they have to wait for an e-tutor when they can contact the lecturer.

Students rather interact with the lecturer on the main site than on the e-tutor site.

A total of 12.9 per cent of the participants felt that they had not received adequate training, which is of great concern. E-tutors who have not received adequate training to work on the system can obviously not work effectively and give the required support and guidance to the students, which is the very reason they were appointed. This concurs with the findings of the study by Du, Ochola, and Wernher (2013) who found that online instructors, e-teachers and/or e-tutors need to be adequately qualified and trained technologically and content-wise - if they were to succeed with online teaching. Some of the responses in this regard were as follows:

I didn't have any sufficient training on how to use the e-tutor system, the little that I know today, I had to teach myself. I am still not 100 per cent comfortable with the system and I believe that I will be able to offer a bigger contribution if I had better training.

I experience a lack of practical training for using all the tools on the system.

According to the participants, the students are also not informed of the role of the e-tutor, which corresponds with the findings of Du, Ochola, and Wernher (2013), Mashile and Matoane (2012), and Matoane and Mashile (2013) who all found that students in an online environment are often left feeling isolated, ill-informed and confused. For instance, students ask questions about their year mark or registration queries on the e-tutor site.

The participants $(9.7 \%)$ responded as follows:

More importantly students are quick to demand their marks from the e-tutors, but e-tutors don't have access to the marks.

I get so many queries with regard to year marks and other administrative queries. It is not my work to provide that sort of information to the students. I don't even have access to that information.

Another challenge, which is largely beyond the control of the ODL institution, is students' access to technology: 9.7 per cent of the participants were of the view that not all students have access to technology. Bharuthram and Kies (2013) correspondingly 
found that students in South Africa generally have a lack of prior exposure to information and communications technology (ICT) systems and this may negatively affect whether they are able to engage in an online learning forum, which is necessary for e-tutoring. Gunga and Ricketts (2007) also found that South Africa has inefficient ICTrelated infrastructure, such as electricity, telecommunications, computers and trained personnel. Billings (2007) adds that one of the major challenges of e-learning is that students must have access to computers and the Internet for this form of online learning to be successful; unfortunately, not all students in South Africa have such access. In fact, in the whole of Africa, there is currently a concern regarding a trend known as the "digital divide". This digital divide, or digital split, is a social issue that refers to the sharp contrast and wide gap between those who have access to the Internet and those who do not (Internet World Stats 2016). Even though the ODL institution where this research was conducted attempts to overcome these digital divisional challenges by offering discounted 3G packages to students and providing Internet access at regional centres, there is still a major problem regarding the lack of Internet access of students in ODL institutions in South Africa (Gunga and Ricketts 2007).

According to Mashile and Matoane (2012), the aim of the e-tutor model is to allocate students to e-tutors who will ensure that the online learning space is managed, thus providing an appropriate learning environment for effective learning. Some of the participants' responses with regard to students' access to technology were as follows:

Access to Internet, specifically to the e-learning system is limited and students from previously disadvantaged communities experience problems in accessing Internet as they live in remote areas.

Some students from disadvantaged places don't have access to computers and Internet. Some students have never used a computer in their entire life, and they are struggling to use the online tools.

Another challenge that the participants (9.7\%) experienced was administrative problems, such as late registrations and the allocation of students to e-tutors. These problems with the administrative process are mainly due to outside factors. For example, the ODL institution involved in this research study experienced a strike early in 2016, which resulted in the registration dates being extended by six weeks. This resulted in students not receiving their study material, nor being allocated to e-tutors in good time. Some of the participants' responses in this regard were as follows:

On the general site there are many students that complain that they are not allocated to an e-tutor yet. E-tutors are allocated later in the semester.

Not receiving any text books and recommended books for the modules one is tutoring. Students are not allocated on time to start on time and prepare [themselves] well in advance.

As discussed earlier in this article, for an e-tutor initiative at an ODL institution to be successful, the most important aspects are participation by both the e-tutor and the 
students, contextualisation of the learning material so that it is meaningful and practical rather than being treated in isolation and out of context - and the presentation of the study material in the online context (Gregory and Salmon 2013).

\section{Theme 2: Solutions to Overcome the Challenges Identified in Theme 1}

\section{Possible Solutions to the Challenges of Lack of Participation and Commitment by Students}

With regard to the above-mentioned challenges, the participants were of the view that students' participation in the online system could be encouraged by allocating a percentage of the students' final mark to participation in the e-tutor system, thus making participation compulsory. The responses received from participants were as follows:

\section{Award Marks for Online Participation}

Allocate the percentage of marks to students using the online system to encourage participation. Participation by students must be compulsory by attaching marks to it.

Participation in discussion forums on the system should contribute a certain percentage towards a year mark, for example 5 per cent. There should be an incentive for the most active students.

A specific percentage mark should be allocated to the students' second assignment if there is regular active participation on the forum.

Incentives such as marks or gifts should be given to students who participate regularly online to motivate other students to participate.

Some sort of incentive for the students' interaction on the discussion forum.

\section{Run Awareness Campaigns}

Students must be provided with e-tutor's email address to assist with problems in learning.

I think e-tutors could share ideas on how to better engage with students. Create an e-tutor forum/ group with biweekly (twice a month) meetings.

As an e-tutor I always post an announcement to welcome them and to tell them to start studying or doing their assignment as soon as they receive their study material. I also send them an SMS to remind them. I always encourage and motivate them to avoid disappointment at a later stage.

I posted a notice on the lecturer site to explain to students where to find me on the site. I also initiated some discussion forums with various topics and when students have questions about certain portions of the work I would highlight this in new discussion forum topics.

Make students more aware of the e-tutors. Promote the e-tutors. Place posters at the respective departments and send students a letter specifically indicating the e-tutors are there to help them.

Better marketing of the e-tutor platform as a solution to any difficulty the students may experience with studying this specific module. 
A comprehensive orientation of students is required. Some of them are not aware that there are e-tutors to help them with their studies.

\section{Make Participation Compulsory}

One way of making the system work is by making it compulsory for each student to take part in at least one group discussion per week. By taking part in the discussions they will be able to realise the benefits of the systems on their own.

I think it is important to make participation compulsory.

Participation by students must be compulsory by attaching marks to it.

\section{Possible Solutions to the Challenges of Lack of Lecturer-E-Tutor Interaction and E-Tutors' Isolation}

The participants were of the view that regular communication between the lecturer and e-tutor, including frequent monitoring and feedback by the lecturer, is necessary to overcome the above-mentioned challenge. Some of the possible solutions raised by the participants were as follows:

\section{Improve Communication (Online/Verbal)}

Better communication between lecturer and e-tutor. It is important to have more trust between the lecturer and e-tutor.

Free information flow between lecturer and e-tutor should take place on a regular basis.

There must be a site for interaction between the primary lecturer and the e-tutors.

\section{Provide Frequent Monitoring and Feedback}

Individual lecturers should monitor e-tutors' performance and communicate expectations of the module to their respective e-tutors.

E-tutors need to be monitored and receive regular feedback from the lecturer and lecturers must attend the e-tutor training workshops.

\section{Suggested Solutions to Overcome the Challenge of Inadequate Training}

Some of the possible solutions mentioned were that e-tutors should receive proper training on the system before their appointment, as well as more workshops, training sessions and online training. The participants' responses were as follows:

It is suggested that e-tutors receive proper training on how to use the e-learning system.

E-tutors should receive training on the e-learning system. There should be more workshops for tutor support; workshops should be held immediately after appointment of e-tutors and not two months later, so that they can quickly adapt to how the institution's systems work. 
Better training should be provided and more opportunities for e-tutors to attend these training sessions as well as providing more than one date and more than one venue in different locations for the e-tutors to attend.

The opportunity for e-tutors to book training to use all the tools inside the e-learning system will improve performance. I believe training schedules should be made available inside this e-learning system.

\section{Suggested Solutions to Overcome the Challenge of Students being Unaware of the E-Tutor's Role}

Possible solutions raised by participants included having clear key performance areas (KPAs) and responsibilities and informing students regularly of the e-tutor's role.

Spell the key performance areas of e-tutor so that learners will understand the role and responsibilities of e-tutors. It should be clear that e-tutors do not perform administrative functions (i.e. assignment administration).

More importantly, students are quick to demand their marks from the e-tutors, but e-tutors don't have access to the marks. This is a role which we cannot perform, although we receive many administrative queries.

Students should be asked what they need or at least indicate that. It is important for the students to understand that e-tutors' function is to give daily support to them.

\section{Suggested Solutions to Overcome the Challenge of Students' Lack of Access to Technology}

The participants concurred that the students' access to technology must be improved. The participants were of the view that the university should provide access to technology in rural areas and that students should receive training in the online system. The participants' suggestions were as follows:

The university should ensure that students from rural areas have access to Internet by fostering partnerships with other stakeholders.

Students need training and mentoring until they understand the system.

Students should be trained on how to participate online.

\section{Suggested Solutions to Overcome the Challenge of Administrative Problems}

According to the participants, possible solutions to overcome the administrative problems included appointing e-tutors earlier in the semester, allocating more students to each e-tutor and appointing more e-tutors:

E-tutor appointments should take place earlier in the semester. 
Registrations close in January. Once registrations have been completed, students and e-tutors must immediately start working because the semester closes end of April and in May the exam starts. Textbooks must be purchased the year prior to be able to have them on time.

To either appoint more e-tutors and it has to be done earlier in the semester.

Allocate more students to an e-tutor and increase the e-tutor's revenue.

\section{SUMMARY OF THE FINDINGS}

The e-tutoring model in the ODL institution where this research study was conducted was implemented to improve students' learning experience and their success rate as well as to provide students with e-tutors who ensure that the online learning space is managed to create an environment for effective learning where students' experiences can be improved, and to enhance success rates.

Table 2 summarises the challenges and solutions developed through this explorative qualitative research study. These suggested solutions can be used as a basis and starting point for further empirical research on the challenges of e-tutoring and online teaching, and even more importantly - the suggested solutions to overcome the challenges of e-tutoring.

Table 2: Challenges and suggested solutions to the e-tutor initiative in an ODL institution

\begin{tabular}{|l|l|}
\hline Challenge & Solution \\
\hline $\begin{array}{l}\text { Low participation or lack of commitment } \\
\text { by students who prefer interaction with } \\
\text { lecturers }\end{array}$ & $\begin{array}{l}\text { Award marks for online participation } \\
\text { Awareness campaigns } \\
\text { Compulsory participation }\end{array}$ \\
\hline $\begin{array}{l}\text { No interaction between lecturer and e-tutor } \\
\text { or isolation of e-tutors }\end{array}$ & $\begin{array}{l}\text { Increase communication (online and verbal) } \\
\text { Regular monitoring and feedback }\end{array}$ \\
\hline Limited training on e-tutor system & $\begin{array}{l}\text { Training before e-tutors are appointed } \\
\text { More workshops and training sessions } \\
\text { Frequent online training }\end{array}$ \\
\hline Students unfamiliar with e-tutors' role & $\begin{array}{l}\text { Set clear KPAs } \\
\text { Inform students of e-tutors' role }\end{array}$ \\
\hline Students' lack of access to technology & $\begin{array}{l}\text { University to provide access to technology in } \\
\text { rural areas } \\
\text { Online training for students }\end{array}$ \\
\hline Administrative problems & $\begin{array}{l}\text { Appoint e-tutors earlier in semester } \\
\text { Allocate more students to an e-tutor } \\
\text { Appoint more e-tutors }\end{array}$ \\
\hline
\end{tabular}

Table 2 summarises the various challenges identified by the participants in this study, as well as the suggested solutions to these challenges. The reason the researchers in 
this study based their framework of solutions to the challenges of e-tutoring on the perceptions and views of the e-tutors is that the e-tutors are the teachers, mentors and contact individuals to the students in this regard. They interact with the students on a regular basis and if their views on the challenges which they experience, and also on the solutions to these challenges, are not taken into serious consideration, the e-tutor model could fail in future. The e-tutors are the energising force that is expected to motivate students and to improve their success and, in that way, to benefit the institution.

\section{CONCLUDING DISCUSSION, RECOMMENDATIONS FOR FUTURE RESEARCH AND LIMITATIONS}

The objectives of the study reported in this article were to determine the challenges experienced by e-tutors, and to suggest possible solutions to improve the e-tutor model and thus contribute to greater student and institutional success.

The results indicated that the e-tutors experience challenges in the form of low participation and lack of commitment by students. The students prefer to interact with their lecturers directly, there is limited or no interaction between lecturers and e-tutors, causing the e-tutors to feel isolated, there is inadequate training for the e-tutors, the students are unclear about the e-tutors' role, students have limited access to technology, and there are various administrative problems.

The participants in this study also suggested various solutions to the challenges which they experience in e-tutoring. Although some of these solutions, such as awareness campaigns, increased communication between lecturers and e-tutors or e-tutors and students, regular monitoring and feedback, e-tutor training, online training for students, frequent online training and informing students of e-tutors' role, are already partially implemented at the ODL institution where this research study was conducted, the researchers agree that the institution should intensify its efforts in implementing these aspects. The institution under examination does provide access to technology in rural areas through the regional centres where students can access computers and the Internet, however, it should be expended to more rural areas in South Africa to benefit more students registered at the institution.

Some of the solutions suggested by the participants such as awarding marks for online participation and making online participation compulsory are impracticable as some students do not have regular access to electronic devices and/or the Internet or are not computer literate. It would therefore be seen as a disadvantage to these students. In the researchers' view it is also not practical to allocate more students to an e-tutor as the quality of the service delivered by the e-tutors to the students would be compromised if e-tutors are overloaded with too many students allocated to them.

The researchers further agree that some solutions suggested by the participants, such as training before e-tutors are appointed, appointing e-tutors earlier in the semester, providing more workshops and training sessions, frequent online training, setting clear 
KPAs and appointing more e-tutors, could and should be implemented by the ODL institution where the research was conducted. The participants' suggested solutions to overcome the challenges of online tutoring can be used as a basis and starting point for further empirical research on the e-tutoring and online teaching. The researchers therefore suggest that ODL institutions take cognisance of the possible solutions suggested by the participants in this study so that student success and institutional competitiveness can be increased.

This study had several limitations. The first limitation was the fact that the study was only performed in one academic department in a single ODL institution. Thus comparison between different departments and different institutions was not possible. Several other departments and ODL institutions should also be considered for future research, as the e-tutor initiative may pose similar challenges in other departments and at other ODL institutions. The second limitation was that only e-tutors' views were taken into account in this study. Further research should be considered on the perceptions of students as well as lecturers, regarding the challenges of e-tutoring as the possible solutions to these challenges.

\section{REFERENCES}

Abdullah, H., and J. Mtsweni. 2014. "The Role of E-Tutors in Promoting E-Learning Using Web 2.0 Technologies." Paper presented at the African Cyber Citizenship Conference, Port Elizabeth, 5-6 November. http://hdl.handle.net/10204/7943.

Bharuthram, S., and C. Kies. 2013. "Introducing E-Learning in a South African Higher Education Institution: Challenges Arising from an Intervention and Possible Responses.” British Journal of Educational Technology 44 (3): 410-20. https://doi.org/10.1111/j.1467-8535.2012.01307.x.

Billings, D. M. 2007. “Understanding the Challenges of E-Learning.” Nursing 2007 37: 36-37. https://doi.org/10.1097/00152193-200701001-00007.

Clark, R. C., and R. E. Mayer. 2003. E-Learning: Promise and Pitfalls. E-Learning and the Science of Instruction. San Francisco: Pfeiffer.

Deketelaere, A., J. Degryse, A. de Munter, and P. de Leyn. 2009. "Twelve Tips for Successful E-Tutoring Using Electronic Portfolios.” Medical Teacher 31 (6): 497-501. https://doi.org/10.1080/01421590802572734.

De Rouin, R. E., B. A. Fritzsche, and E. Salas. 2004. “Optimizing E-Learning: Research-Based Guidelines for Learner-Controlled Training.” Human Resource Management 43 (2-3): 147-62. https://doi.org/10.1002/hrm.20012.

Du, S., E. O. Ochola, and F. Wernher. 2013. "Improving Open Distance Learning Efficiency by NonInvasive Brain Computer Interface." Paper presented at the 4th Annual International Conference on Computer Science Education: Innovation and Technology (CSEIT), Singapore, 26-31 October. http://hdl.handle.net/10500/8740. 
E-Connect (Unisa staff online). 2015. "Facilitation of Learning: Tutorial Support Services.” Accessed 25 July 2015. http://www.unisa.ac.za/sites/myunisa/default/Learner-support-\&-regions/TuitionSupport.

Gregory, J., and G. Salmon. 2013. "Professional Development for Online University Teaching.” Distance Education 34 (3): 256-70. https://doi.org/10.1080/01587919.2013.835771.

Gunga, S. O., and I. W. Ricketts. 2007. "Facing the Challenges of E-Learning Initiatives in African Universities.” British Journal of Educational Technology 38 (5): 896-906. https://doi.org/10.1111/j.1467-8535.2006.00677.x.

Heydenrych, J. F., P. Higgs, and L. J. van Niekerk. 2003. "Implementing the Online Learning Community in Africa: A Unisa Case Study.” African and Asian Studies 2 (4): 421-74. https://doi.org/10.1163/156920903773004013.

Holmberg, B. 1995. Theory and Practice of Distance Education. London: Routledge.

Internet World Stats. 2016. The Digital Divide, ICT, and Broadband Internet. Accessed 25 July 2015. http://www.internetworldstats.com/links10.htm.

Kilfoil, W. R. n.d. "Integrating the Elements of Open Distance Learning (ODL) to Enhance Service to Students in a Developing Country.” https://wikieducator.org/images/9/90/PID_331.pdf.

Krefting, L. 1991. "Rigor in Qualitative Research: The Assessment of Trustworthiness.” American Journal of Occupational Therapy 45 (3): 214-22. https://doi.org/10.5014/ajot.45.3.214.

Leedy, P. D., and J. E. Ormrod. 2010. Practical Research, Planning and Design. 9th ed. New Jersey: Pearson Education International.

Mashile, E. O., and M. C. Matoane. 2012. “E-Learning Development: The Case of Unisa.” Paper presented at the E-Learn: World Conference on E-Learning in Corporate, Government, Healthcare, and Higher Education, Montreal, 9 October.

Mashile, E. O., and F. J. Pretorius. 2003. "Challenges of Online Education in a Developing Country.” South African Journal of Higher Education 17 (1): 132-9. http://dx.doi.org/10.4314/sajhe.v17i1.25202.

Matoane, M., and E. O. Mashile. 2013. "Key Considerations for Successful E-Tutoring: Lessons Learnt from an Institution of Higher Learning in South Africa." Paper presented at the E-Learn: World Conference on E-Learning in Corporate, Government, Healthcare, and Higher Education, Las Vegas, 21 October. https://www.learntechlib.org/p/114955/.

Mouton, J. 2001. How to Succeed in Your Master's and Doctoral Studies: A South African Guide and Resource Book. Pretoria: Van Schaik.

Muirhead, B. 2007. "Interactivity Challenges Facing Online Educators.” Paper presented at the Twelfth Cambridge Conference on Open and Distance Learning. Cambridge, 4 September.

Qualitative Research Guidelines Project. 2008. “The Interpretivist Paradigm.” Accessed 10 January 2018. http://www.qualres.org/HomeInte-3516.html. 
Quon, P. 2006. "The Effect of Group Interaction, Study Schedule, Tutor Support and Student Attributes on Persistence and Achievement in Distance Education.” Master's thesis, Athabasca University. https://auspace.athabascau.ca/bitstream/handle/2149/571/1/pamelaquonThesis-revised.pdf.

Rice, P. L., and D. Ezzy. 2002. Qualitative Research Methods: Health Focus. Oxford: Oxford University Press.

Saunders, M., P. Lewis, and A. Thornhill. 2009. Research Methods for Business Students. 5th ed. Harlow: Prentice Hall.

Schonfeld, T. L. 2005. "Reflections on Teaching Health Care Ethics on the Web." Science and Engineering Ethics 11 (3): 481-94. https://doi.org/10.1007/s11948-005-0018-z.

Silverman, D. 2002. Doing Qualitative Research: A Practical Handbook. London: Sage.

Stern, A. 2015. "Bridge the Gap: Replicating the Interactivity of the Physical Classroom in an Online Environment.” History Teacher 48 (3): 483-504.

Tesch, K. 1990. Qualitative Research: Analysis, Types and Software Tools. New York: Falmer Press.

Todhunter, B. 2013. "LOL — Limitations of Online Learning — Are We Selling the Open and Distance Education Message Short?” Distance Education 34 (2): 232-52.

https://doi.org/10.1080/01587919.2013.802402.

Townsend, M., and S. Wheeler. 2004. "Is There Anybody Out There? Teaching Assistants' Experiences of Online Learning.” Quarterly Review of Distance Education 5 (2): 127-38. 